\title{
Cytocompatibility of Medical Biomaterials Containing Nickel by Osteoblasts: a Systematic Literature Review
}

\author{
Marcin Mikulewicz • Katarzyna Chojnacka
}

Received: 6 July 2010 / Accepted: 29 July 2010 /

Published online: 12 August 2010

(C) The Author(s) 2010. This article is published with open access at Springerlink.com

\begin{abstract}
The present review is based on a survey of 21 studies on the cytocompatibility of medical biomaterials containing nickel, as assessed by cell culture of human and animal osteoblasts or osteoblast-like cells. Among the biomaterials evaluated were stainless steel, $\mathrm{NiTi}$ alloys, pure $\mathrm{Ni}, \mathrm{Ti}$, and other pure metals. The materials were either commercially available, prepared by the authors, or implanted by various techniques to generate a protective layer of oxides, nitrides, acetylides. The observation that the layers significantly reduced the initial release of metal ions and increased cytocompatibility was confirmed in cell culture experiments. Physical and chemical characterization of the materials was performed. This included, e.g., surface characterization (roughness, wettability, corrosion behavior, quantity of released ions, microhardness, and characterization of passivation layer). Cytocompatibility tests of the materials were conducted in the cultures of human or animal osteoblasts and osteoblast-like cells. The following assays were carried out: cell proliferation and viability test, adhesion test, morphology (by fluorescent microscopy or SEM). Also phenotypic and genotypic markers were investigated. In the majority of works, it was found that the most cytocompatible materials were stainless steel and NiTi alloy. Pure $\mathrm{Ni}$ was rendered and less cytocompatible. All the papers confirmed that the consequence of the formation of protective layers was in significant increase of cytocompatibility of the materials. This indicates the possible further modifications of the manufacturing process (formation of the passivation layer).
\end{abstract}

Keywords Cytocompatibility $\cdot \mathrm{Nickel} \cdot$ Osteoblasts $\cdot$ Cell proliferation $\cdot$ Cell viability

M. Mikulewicz

Department of Dentofacial Orthopedics and Orthodontics, Medical University of Wrocław, Wrocław, Poland

K. Chojnacka

Institute of Inorganic Technology and Mineral Fertilizers, Wrocław University of Technology, Wrocław, Poland

M. Mikulewicz $(\bowtie)$

ul. Krakowska 26, 50-425 Wrocław,

Poland

e-mail: mmikulewicz@poczta.onet.pl 


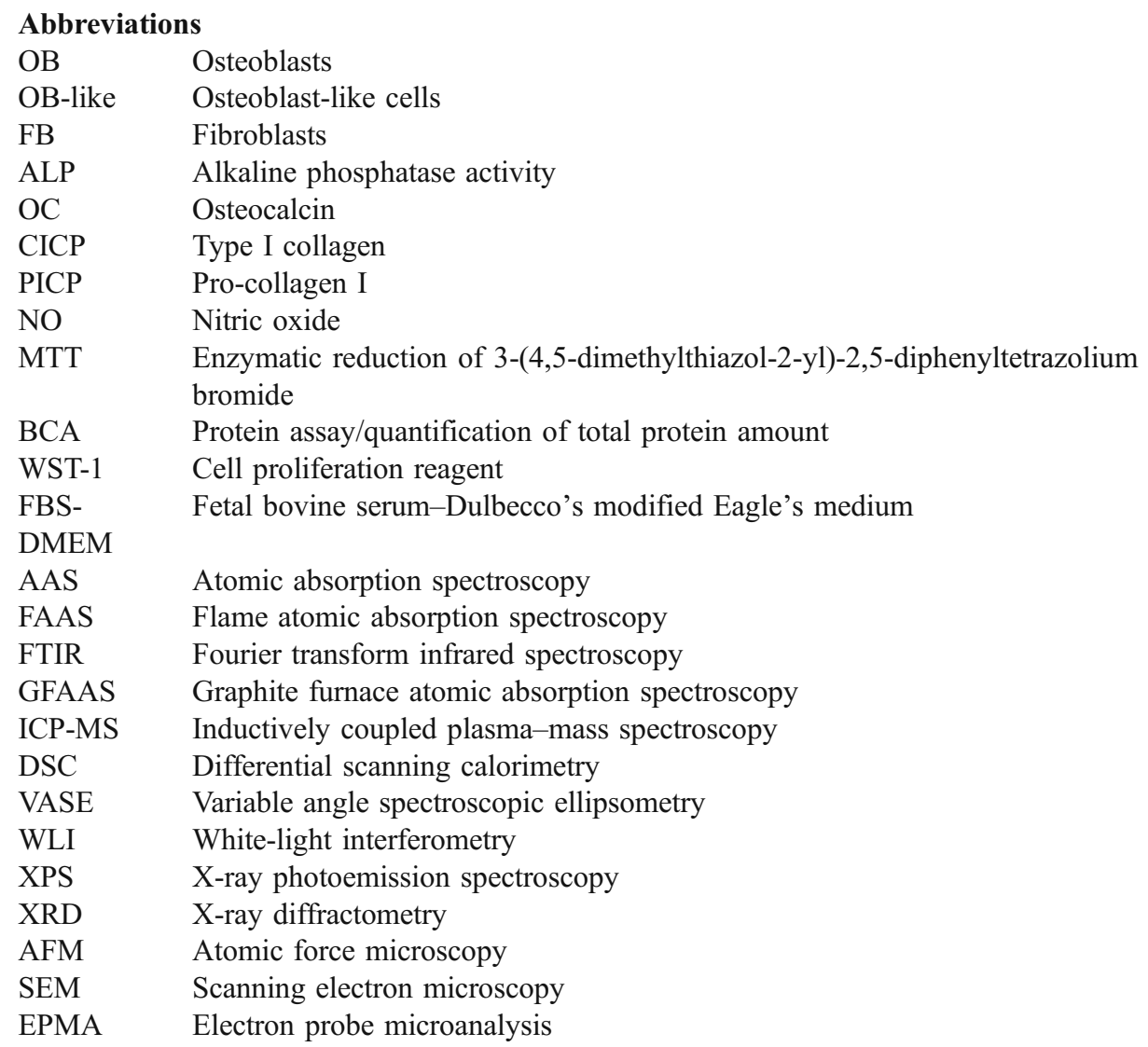

\section{Introduction}

There are certain requirements towards all the materials (implants or dental appliances) which are inserted in human body. The following problems are considered: biological safety tissue response, biofunctionality and corrosion resistance. Also, technological and economic aspects are important [1]. Many of those aspects are covered by biocompatibility approach. It seems that the applied biomaterials should possess two significant features. The first aspect is integrity and degradation of the material and the second is the reaction of the host organism (toxic effects and allergic response) [2]. Alloys should be biocompatible and present required mechanical properties (resistance to stress and wear) [3].

The application of orthodontic devices (brackets, bands, and wires) in the oral cavity requires evaluation of biocompatibility of the materials. The latter is related with the susceptibility for ion release, corrosion resistance, and ability to create a passivation layer. Valid definitions of biocompatibility were given by Black (1984) [4] and Williams (1998) [5]. The term was defined as the response of a host organism to the presence of potentially inert biomaterials. Biocompatibility studies usually include investigation of histopathological changes in host which was exposed to the material for an extended period of time. Host response is a measure of biocompatibility [6]. In order to make the results of biocompatibility studies comparable, the guidelines and procedures were included in ASTM and ISO standards $[7,8]$. 
Previously, the problem of corrosion of orthodontic appliances and resulting ions release in in vitro and in vivo conditions was discussed $[9,10]$. The objective of the present work was to review systematically cytocompatibility of the materials by cell culture experiments on osteoblasts (OB) and osteoblast-like cells. In the available literature, no systematic review discussing this topic was found.

\section{Materials and Methods}

The following search criteria were selected to find papers describing the cytocompatibility of metal alloys containing Ni applied for medical purposes by osteoblast and osteoblast-like cell cultures. The search consisted of the following criteria: cytocompatibility (or biocompatibility) and osteoblast and nickel (or Ni-Ti or NiTi or Nitinol or "stainless steel"). The combinations of keywords and search results are presented in Table 1. To find articles which can match the mentioned criteria, a search in PubMed database was conducted (from 1966 to April 2010).

The keyword "cytocompatibility" was extended with "biocompatibility," because cytocompatibility is a particular case of biocompatibility, which is the wider term. To the keyword "nickel," additional keywords "or Ni-Ti or NiTi or Nitinol" or "stainless steel" were added because not all papers which discussed cytocompatibility of materials potentially release nickel, the words "nickel" and "stainless steel" were included in title and abstract section, and $\mathrm{Ni}-\mathrm{Ti}, \mathrm{NiTi}$, and Nitinol are the most frequently used terms for superelastic alloys containing nickel, applied in orthodontics and orthopedics. The keyword "nickel" was selected, because this metal and its potential toxicity are of particular concern. All the articles that met the inclusion criteria of the systematic review were selected for the study. Eligibility of the selected studies was determined by reading the abstracts of papers identified by the search. The abstracts of related articles were reviewed to search for any similar studies. Following exclusion criteria were applied: other than English papers, exposure to nickel from materials other than those used in orthodontic and orthopedic treatment, reviews, case reports, or papers concerning topics other than cytocompatibility tests by osteoblasts.

Table 1 PubMed search strategy

\begin{tabular}{|c|c|c|}
\hline No. & Word or phrase & Results \\
\hline $1 \mathrm{a}$ & Cytocompatibility & 535 \\
\hline $1 b$ & Biocompatibility & 9,142 \\
\hline 2 & Osteoblast & 25,016 \\
\hline $3 \mathrm{a}$ & Nickel & 24,687 \\
\hline $3 b$ & $\mathrm{Ni}-\mathrm{Ti}$ & 1,436 \\
\hline $3 \mathrm{c}$ & NiTi & 688 \\
\hline $3 d$ & Nitinol & 1,810 \\
\hline $3 e$ & "Stainless Steel” & 10,745 \\
\hline 5 & $(1 \mathrm{a}$ or $1 \mathrm{~b})$ & 9,142 \\
\hline 6 & $(1 \mathrm{a}$ or $1 \mathrm{~b})$ and 2 & 598 \\
\hline 7 & $(3 \mathrm{a}$ or $3 \mathrm{~b}$ or $3 \mathrm{c}$ or $3 \mathrm{~d}$ or $3 \mathrm{e})$ & 36,155 \\
\hline 8 & $(1 \mathrm{a}$ or $1 \mathrm{~b})$ and 2 and $(3 \mathrm{a}$ or $3 \mathrm{~b}$ or $3 \mathrm{c}$ or $3 \mathrm{~d}$ or $3 \mathrm{e})$ & 43 \\
\hline
\end{tabular}




\section{Results}

The PubMed search identified 43 studies [11-53]. No additional search in other databases was performed. From 43 identified studies, 21 met the selection criteria [33-53]. Excluded studies [11-32] — with the reported reason of exclusion — are presented in Table 2. Included studies are listed in Table 3.

Tables 3, 4, and 5 present the materials, methodology, and results. Because of severe differences in applied methodology, it was impossible to conduct quantitative statistical elaboration of the results reported in various papers. The main characteristics investigated in the evaluation of the biomaterials included physical and chemical properties, biocompatibility by culturing $\mathrm{OB}$ or fibroblasts (FB; proliferation and viability tests) and by phenotypic biomarkers, e.g., ALP (alkaline phosphatase activity), OC (Osteocalcin), CICP (Type I C-terminal collagen propeptide), as well as bioadhesion.

Table 3 discusses the properties of evaluated materials. The main biomedical applications investigated were orthopedic implantology, surgery, and orthodontics.

The Type of Materials and Additional Processing

The type of the material included stainless steel (316 L [33, 34, 40, 42, 43], 316LS [37, 52], P558 [39, 40, 44], Stst not specified [35, 38, 44, 51]), NiTi (different types) [34, 36, 41, 43,

Table 2 Studies that fulfilled the selection criteria but were excluded from the "Results" section [11-32]

Authors, date Reason for exclusion

\begin{tabular}{|c|c|c|}
\hline [11] & Arslan et al., 2008 & Different topic \\
\hline [12] & Berger-Gorbet et al., 1996 & Different material-NiTi screws \\
\hline [13] & Bogdanski et al., 2002 & In German \\
\hline [14] & Bombonato-Prado et al., 2009 & Different topic-expression of genes \\
\hline [15] & Bosetti et al., 2002 & Different material—silver coated \\
\hline [16] & Brors et al., 2002 & Different topic \\
\hline [17] & Brunot et al., 2007 & Different topic \\
\hline [18] & Diaz et al., 2008 & Different topic \\
\hline [19] & González-Carrasco et al., 2005 & Different topic \\
\hline [20] & Gough and Downes, 2001 & Different topic \\
\hline [21] & Kapanen et al., 2002 & Different topic_-surface stresses \\
\hline [22] & Kapanen et al., 2002 & Different topic_-surface stresses \\
\hline [23] & Li et al., 2006 & In Chinese \\
\hline [24] & Macnair et al., 1997 & Different material—orthopedic polymers \\
\hline [25] & Misra et al., 2010 & Different material—nanograined/ultrafine-grained \\
\hline [26] & Morais and Pereira, 2000 & Different topic \\
\hline [27] & Nicula et al., 2007 & Different topic \\
\hline [28] & Petrolati et al., 1999 & Different topic \\
\hline [29] & Santavirta et al., 1992 & Different topic \\
\hline [30] & Shahryari et al., 2009 & Different topic \\
\hline [31] & Tschon et al., 2005 & Different topic_-soft tissue response \\
\hline [32] & Woodruff et al., 2007 & Different topic \\
\hline
\end{tabular}




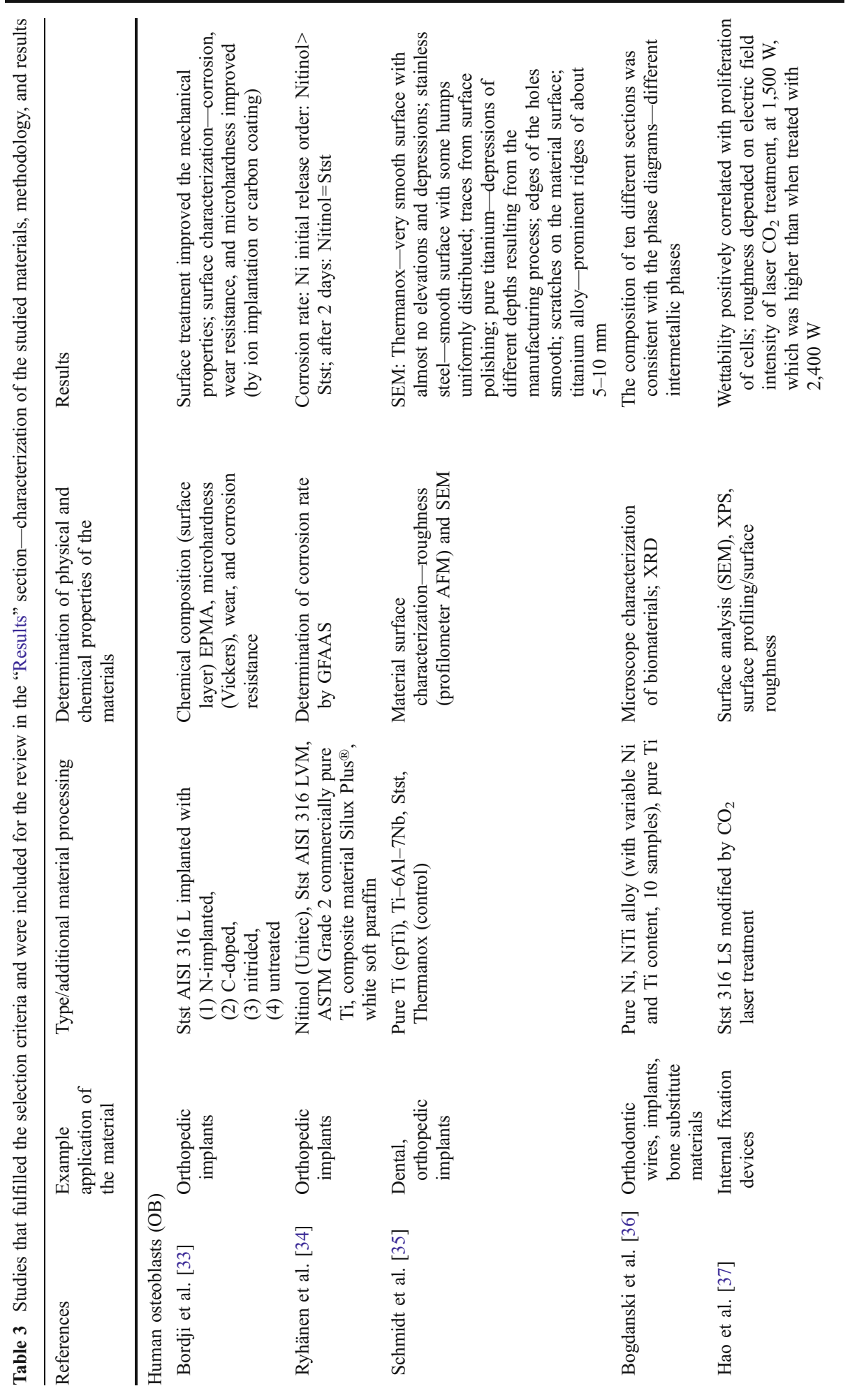




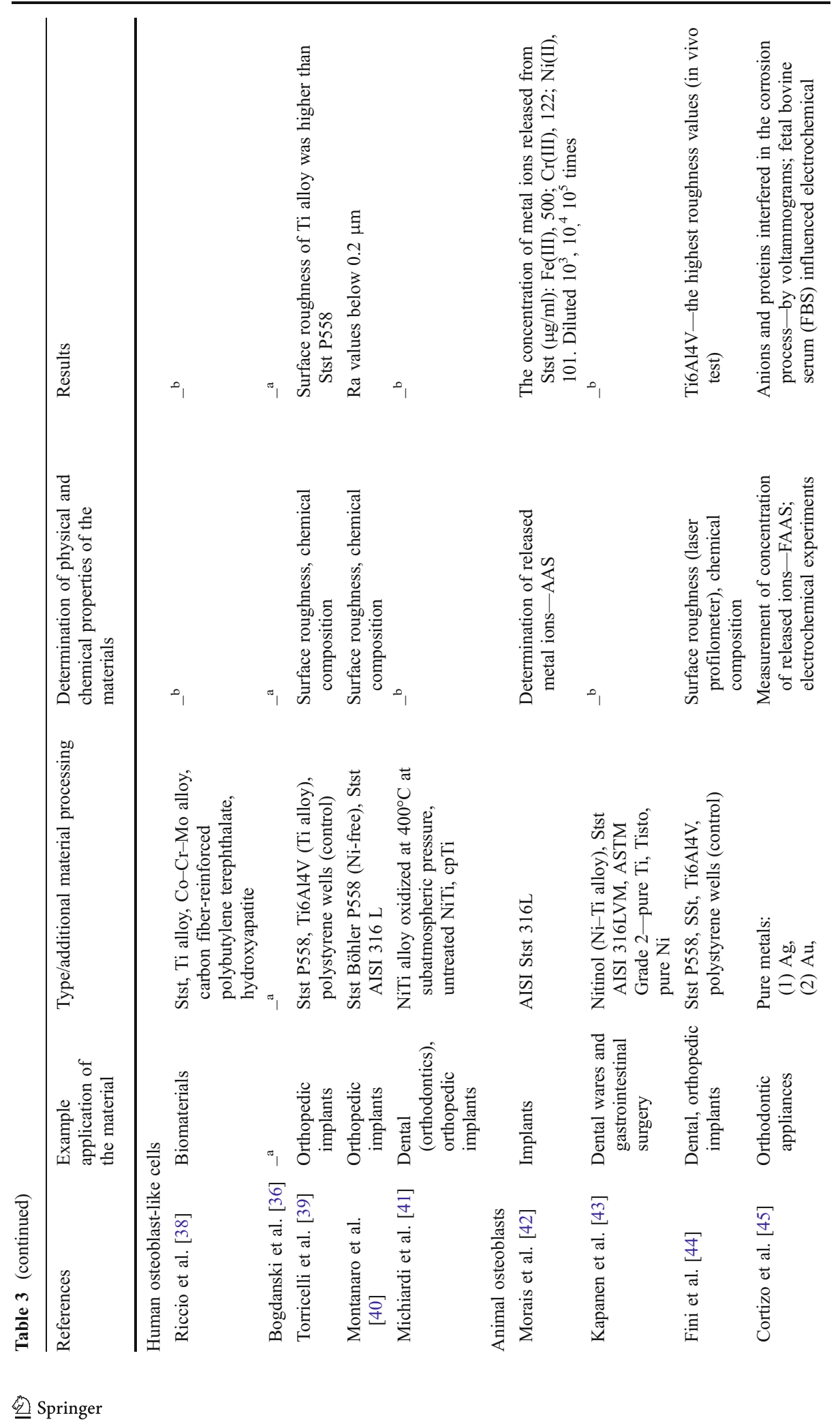




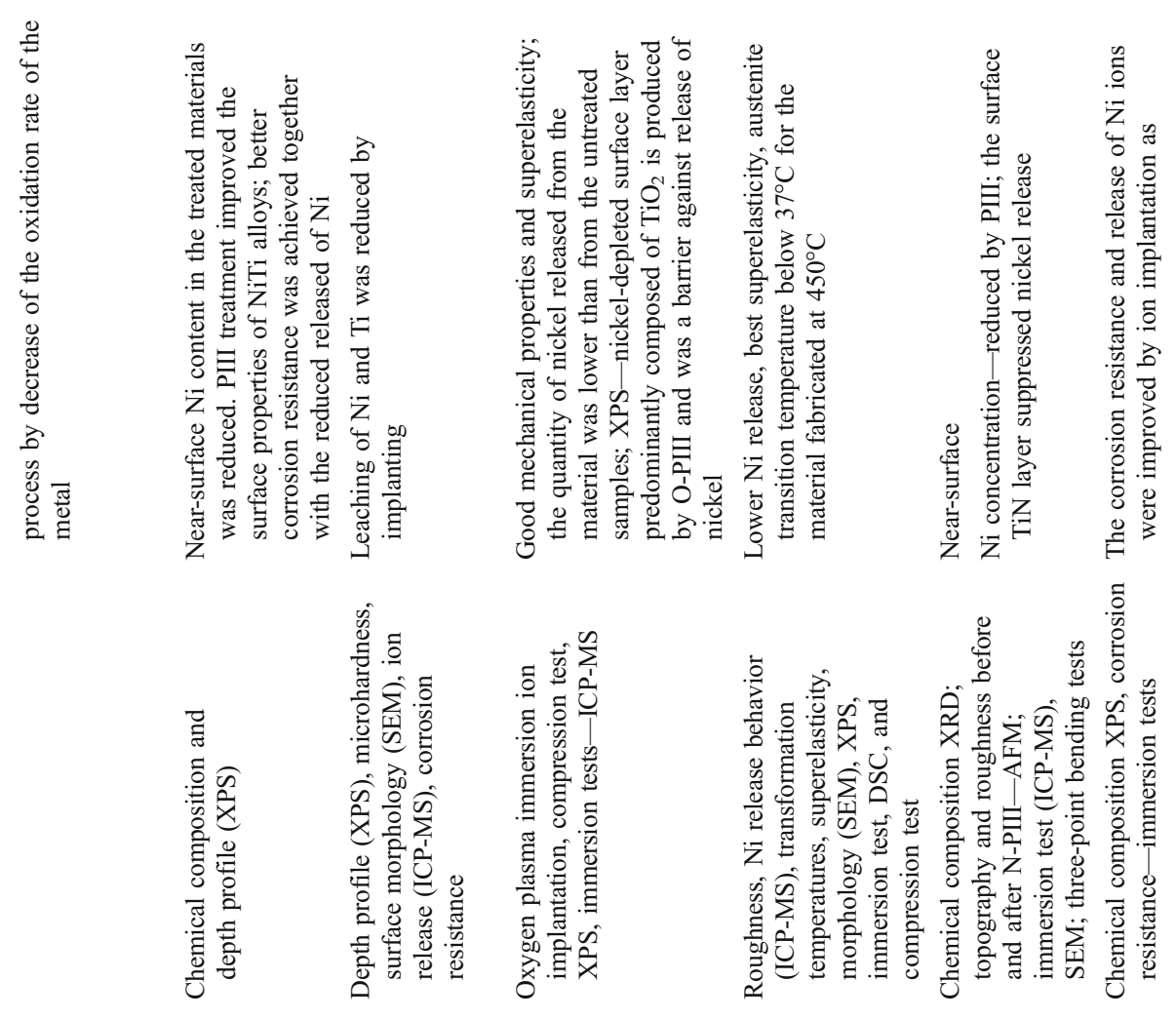

嘕

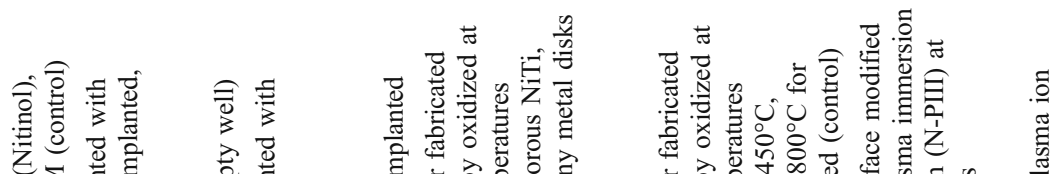

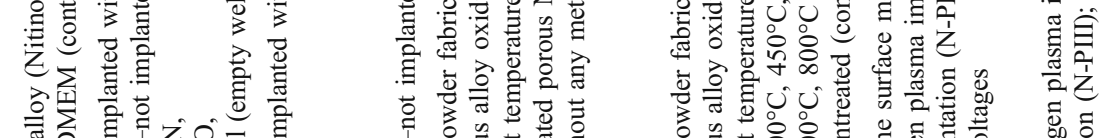

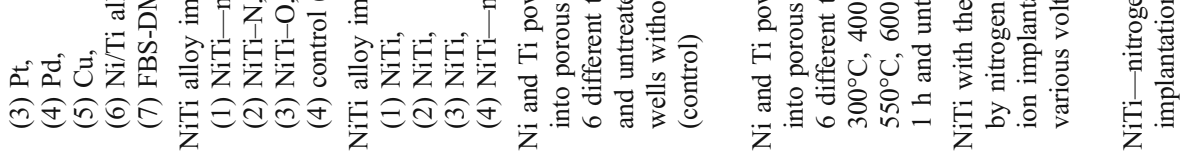

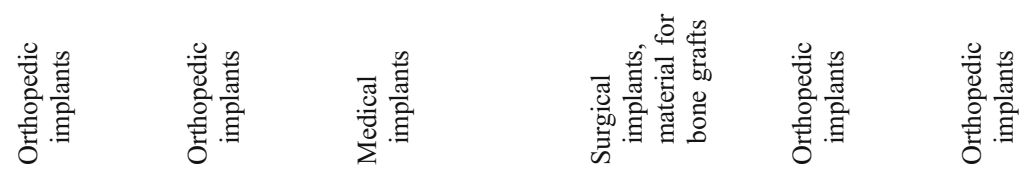

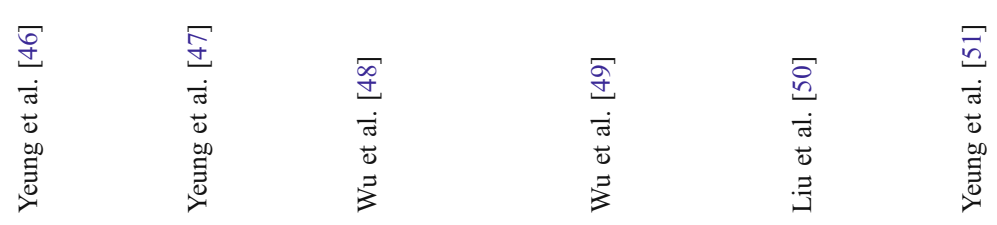




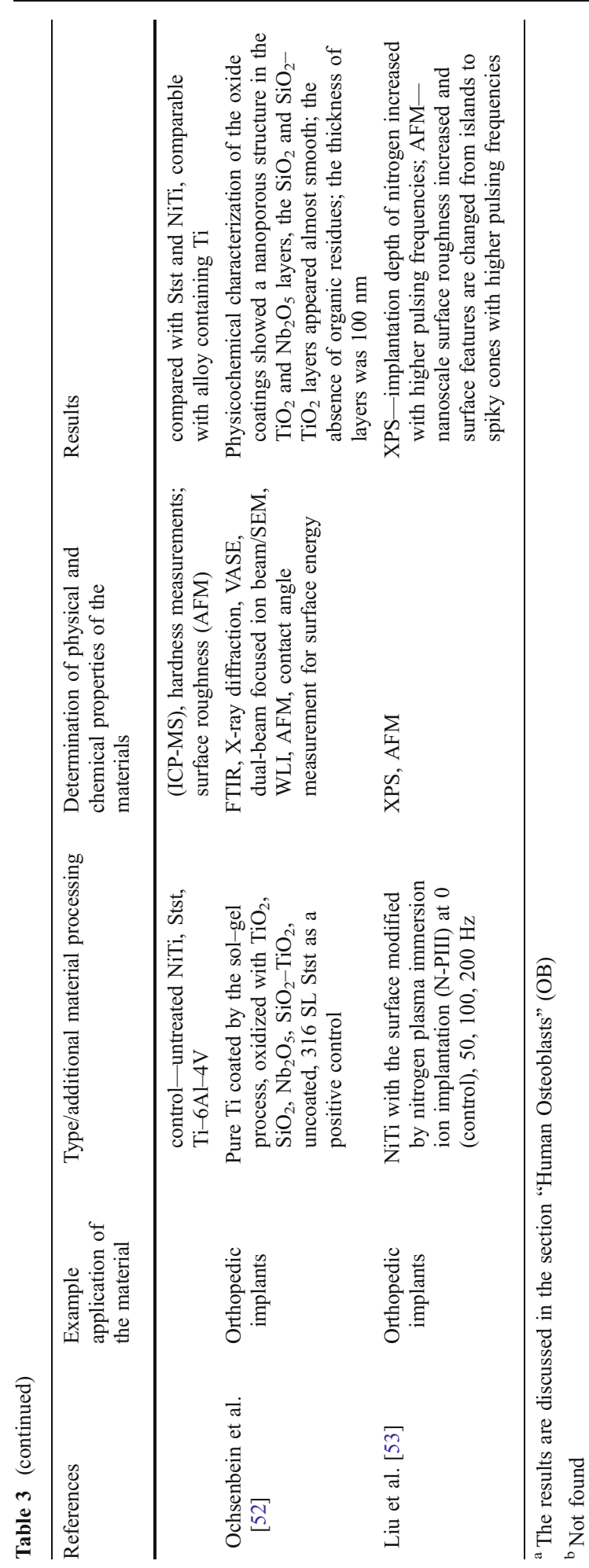




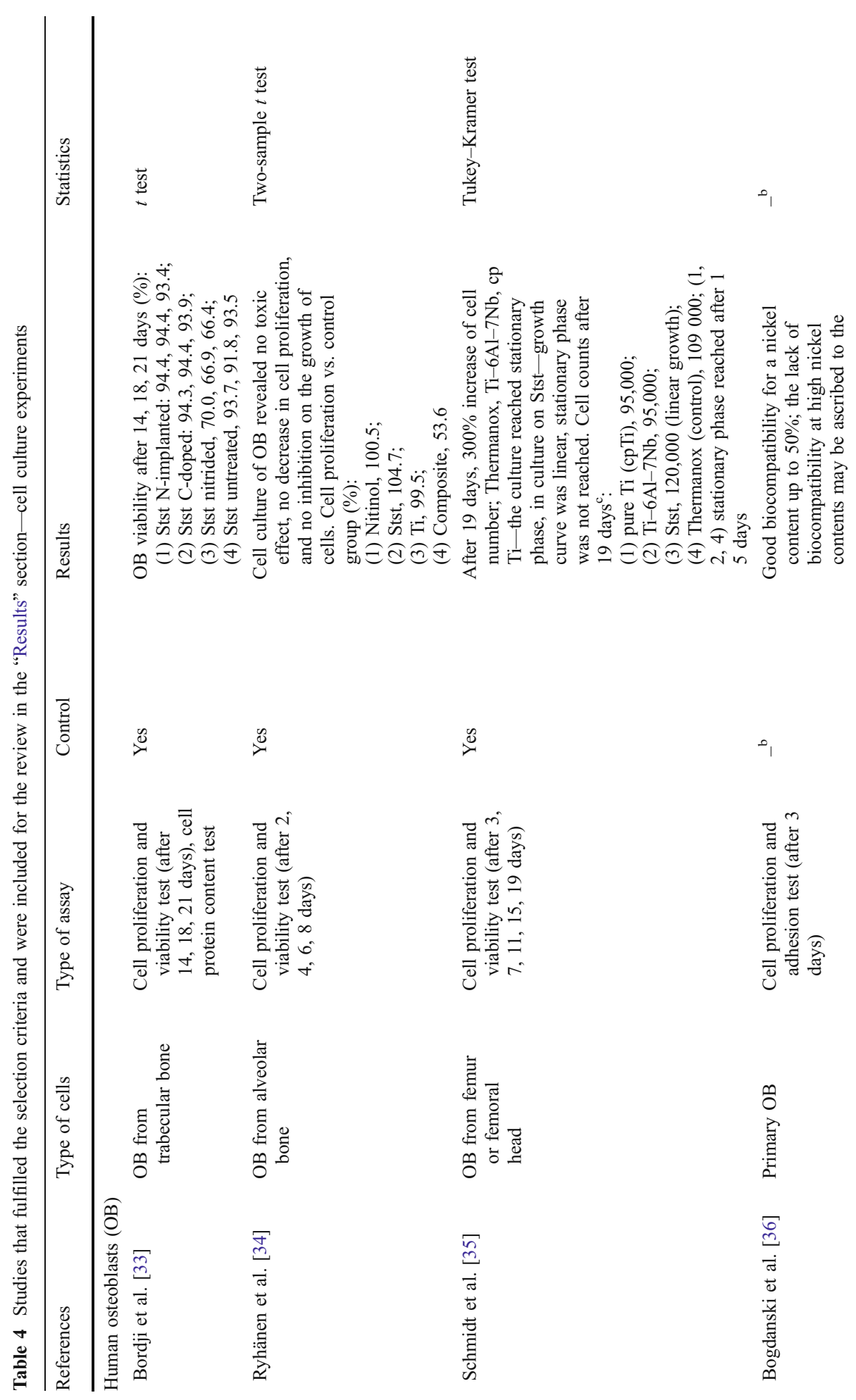




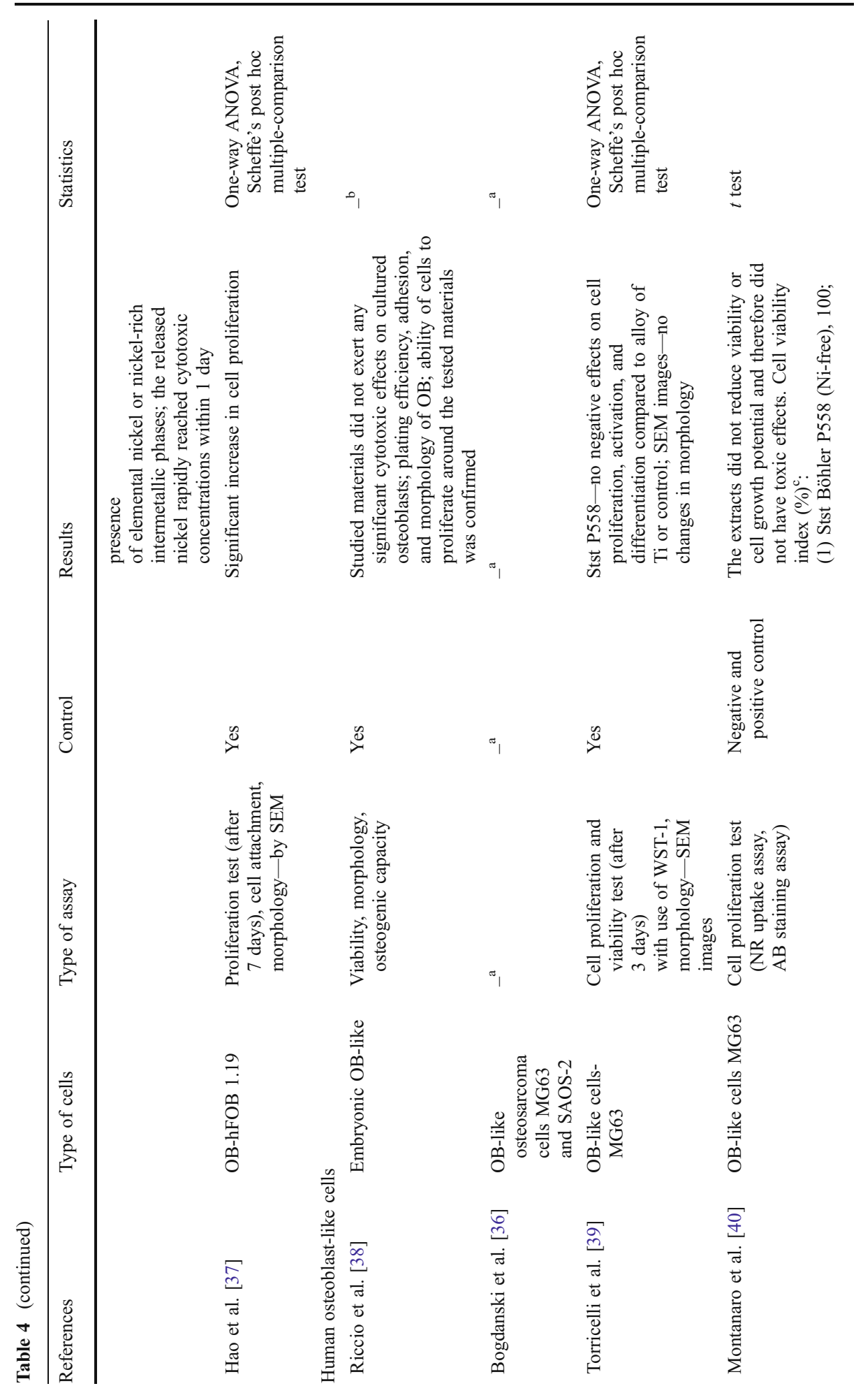



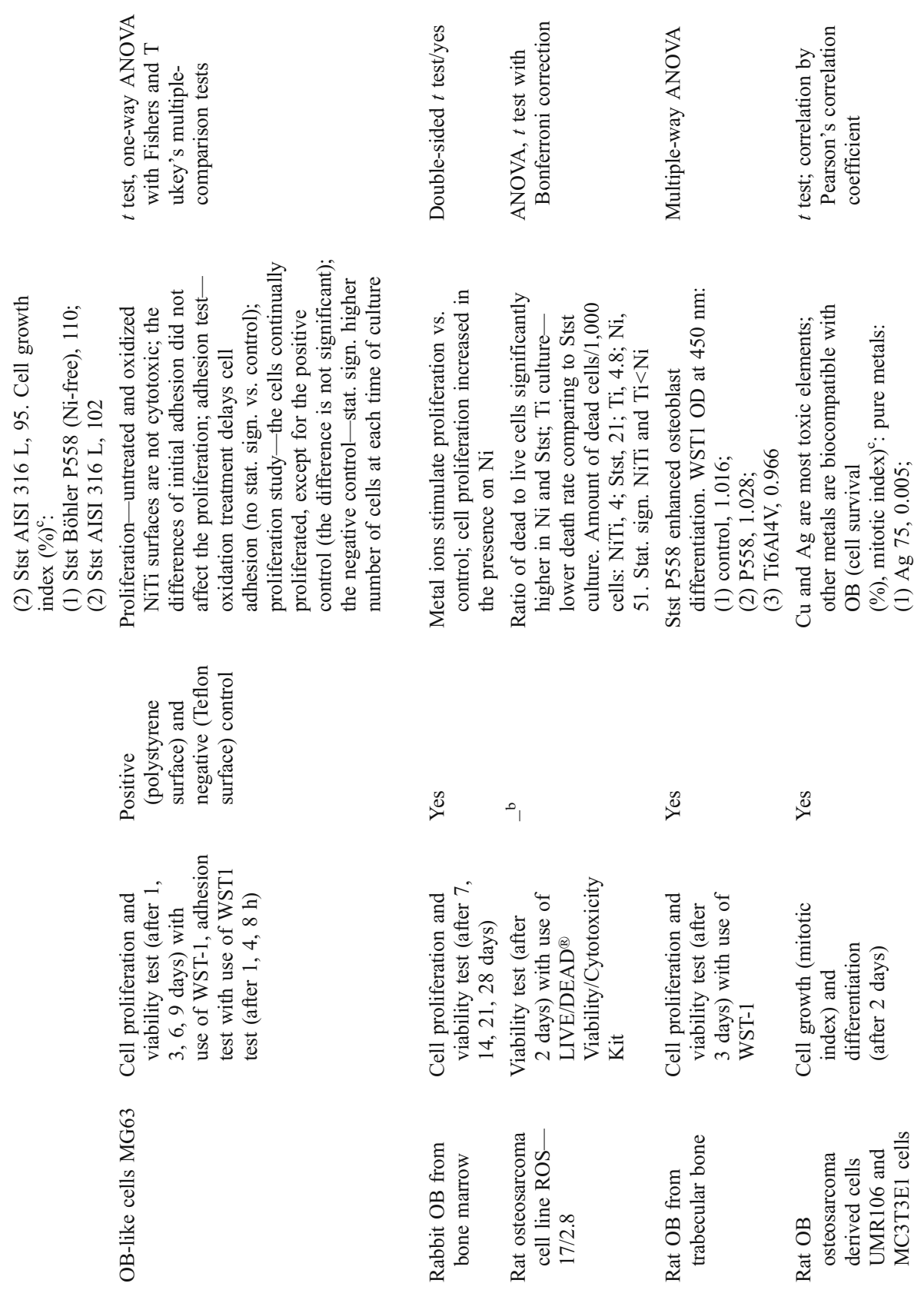

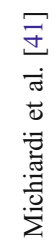

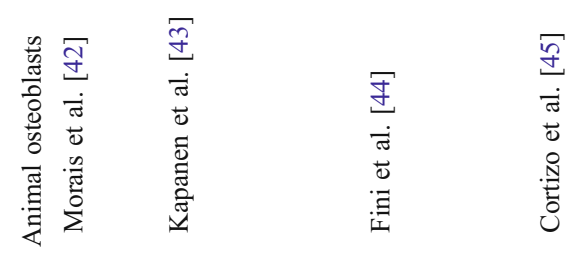




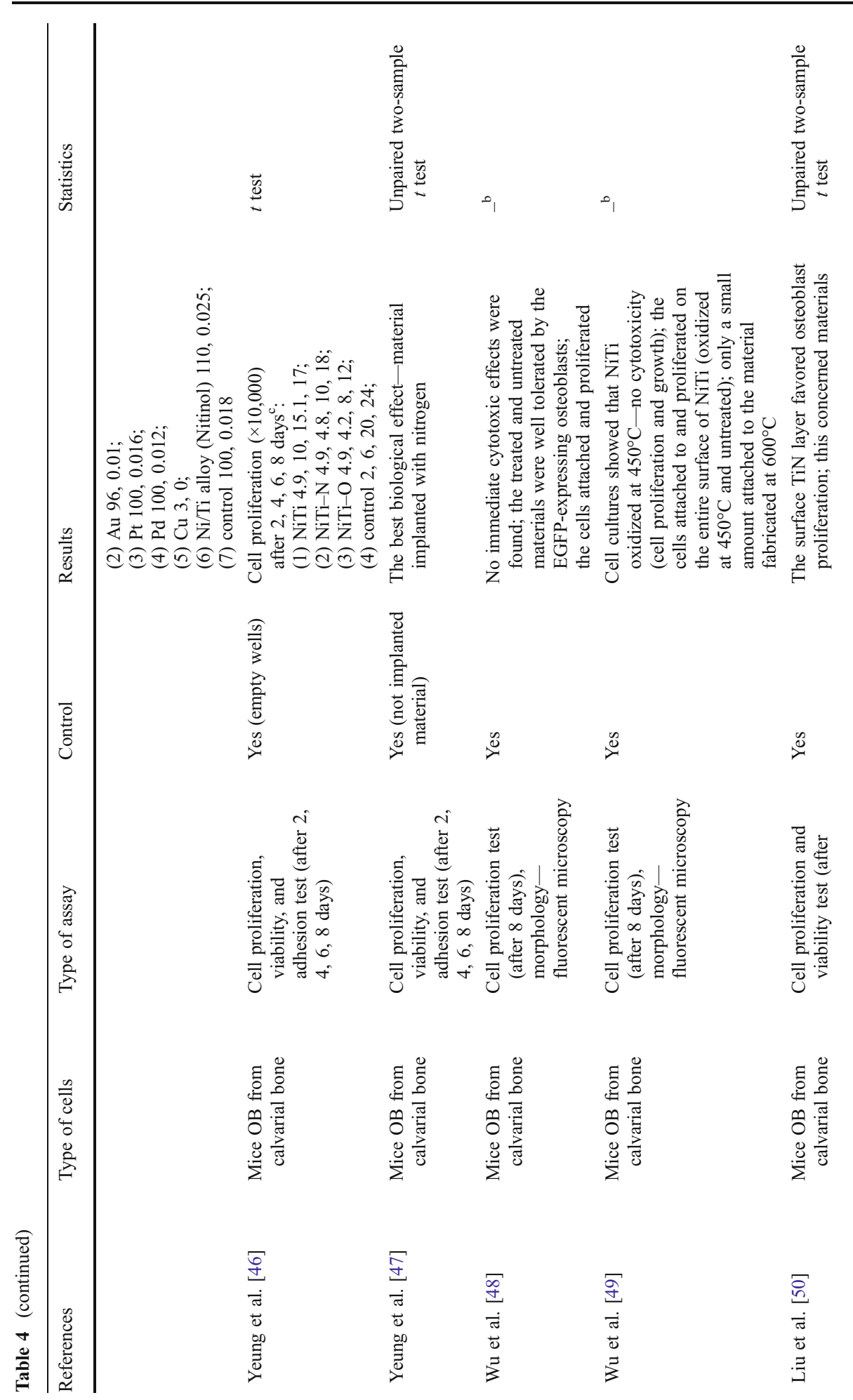



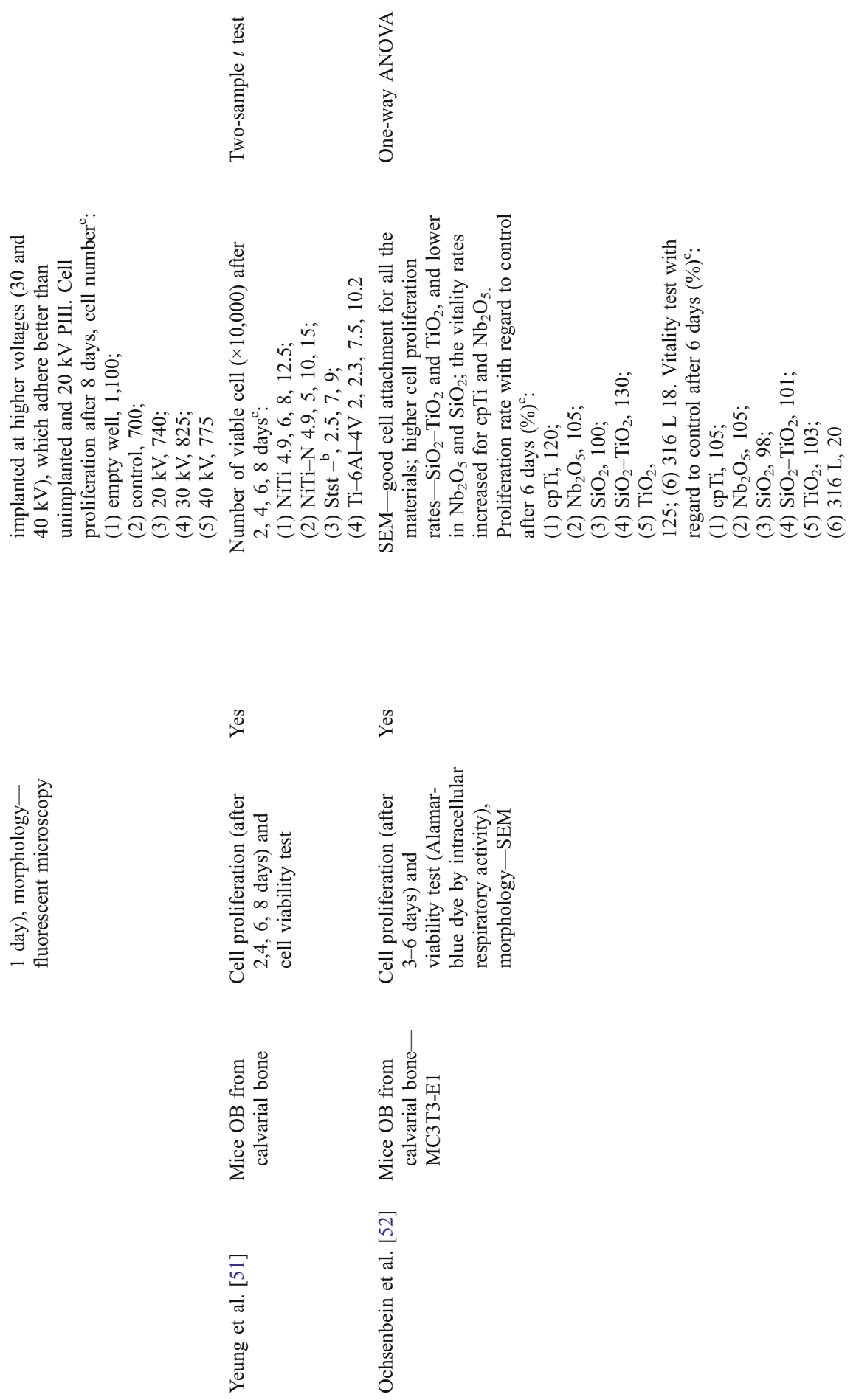


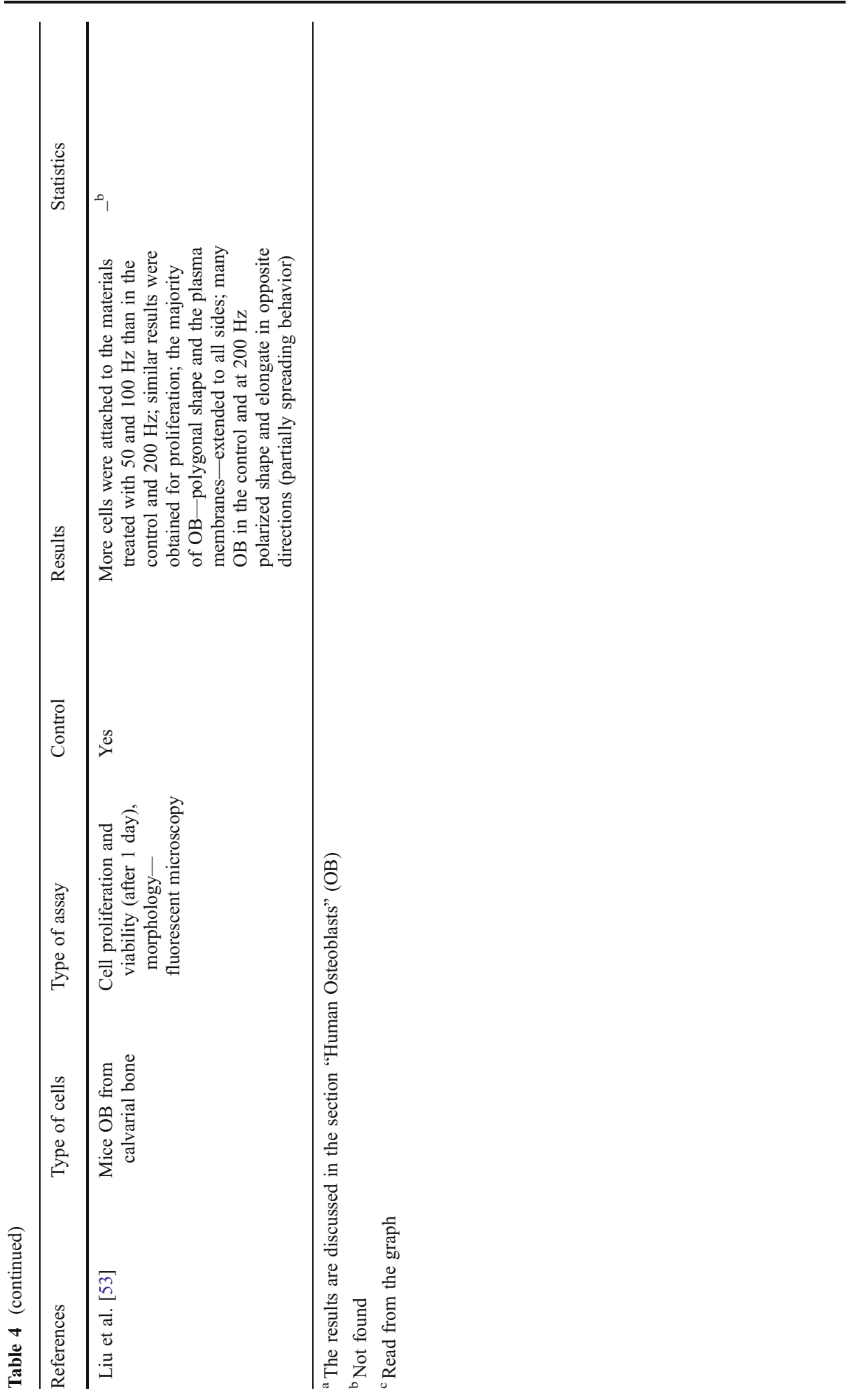


45-51, 53], pure Ni [36, 43] and pure Ti [34-36, 43, 52], Ti alloy (Ti-6Al-4V [39, 44, 51], Ti-6Al-7Nb [35]), Co-Cr-Mo alloy, carbon fiber-reinforced polybutylene terephthalate, ultra-high molecular weight polyethylene, ceramic, calcium phosphate, and hydroxyapatite [38]. The following materials served as the control: composite material Silux Plus ${ }^{\circledR}$ [34], Thermanox [35], polystyrene [39, 44], growth medium (e.g., FBS-DMEM) [45], and white soft paraffin [34]. In many studies, the properties of untreated and treated (high voltage, oxidization, nitridization, and ion implantation) materials were conducted.

\section{Physical and Chemical Properties of the Materials_-Methods}

In the majority of papers, physical/chemical properties of the materials were evaluated. Different methodological approaches have been applied. The basic characteristics were as follows: the chemical composition of the materials (XRD [36, 50, 52], XPS [37, 46-49, 51, 53], EPMA [33], and not specified [39, 40, 44]), the quantity of ions released (immersion tests-ICP-MS, FAAS, GFAAS, AAS [34, 42, 45, 47-51]), corrosion resistance [33, 47, 51], wear resistance [33], microhardness [33, 47, 51], surface roughness (profilometry, AFM [35, 37, 39, 40, 44, 49-53]), surface morphology (SEM [35, 37, 47-50, 52]), threepoint bending test [50], compression test [48, 49], transformation temperature [49], superelasticity [49], DSC [49], FTIR [52], VASE [52], and WLI [52]. The expected properties of the materials depend on their application, e.g., higher surface roughness is requested in orthopedic implants (better osteointegration), but lower in orthodontic wires (lower friction).

\section{Physical and Chemical Properties of the Materials-Results}

The main conclusion arising from the performed studies was that the applied treatment improved the formation of the passivation layer (oxides, nitrides, and acetylides) which was protective against the release of metal ions from the material and consequently improved the biocompatibility. Practically, in all the studies, the initial release of metal ions was confirmed. If the materials were treated, this phenomenon was not so significant. This initial release was followed by the formation of the passivation layer. In the case of treated materials, this layer was formed under controlled conditions during the manufacturing process.

Table 4 discusses cell culture experiments - materials, methods, and results.

\section{Cell Culture Experiments-Type of Cells}

Mainly three types of cells were investigated (Table 4): human OB (bone, primary, cell line) [33-37], human osteoblast-like cells (OB-like; osteosarcoma cells MG63, SAOS-2, embryonic) [38-41], and animal $\mathrm{OB}$ (rabbits, mice, rats; osteosarcoma, bone-mainly calvaliar) [42-53]. Since the cell culture experiments were carried out on different types of cells (human OB and OB-like cells, as well as animal OB), it is difficult to compare the experimental results. However, it is possible to relate interpretations and conclusions.

\section{Cell Culture Experiments-Type of Assay}

Cells were cultivated under laboratory conditions, and the following types of assays were performed: cell proliferation (hemacytometer), cell viability (cell counts), and morphology by SEM [33-53]. 


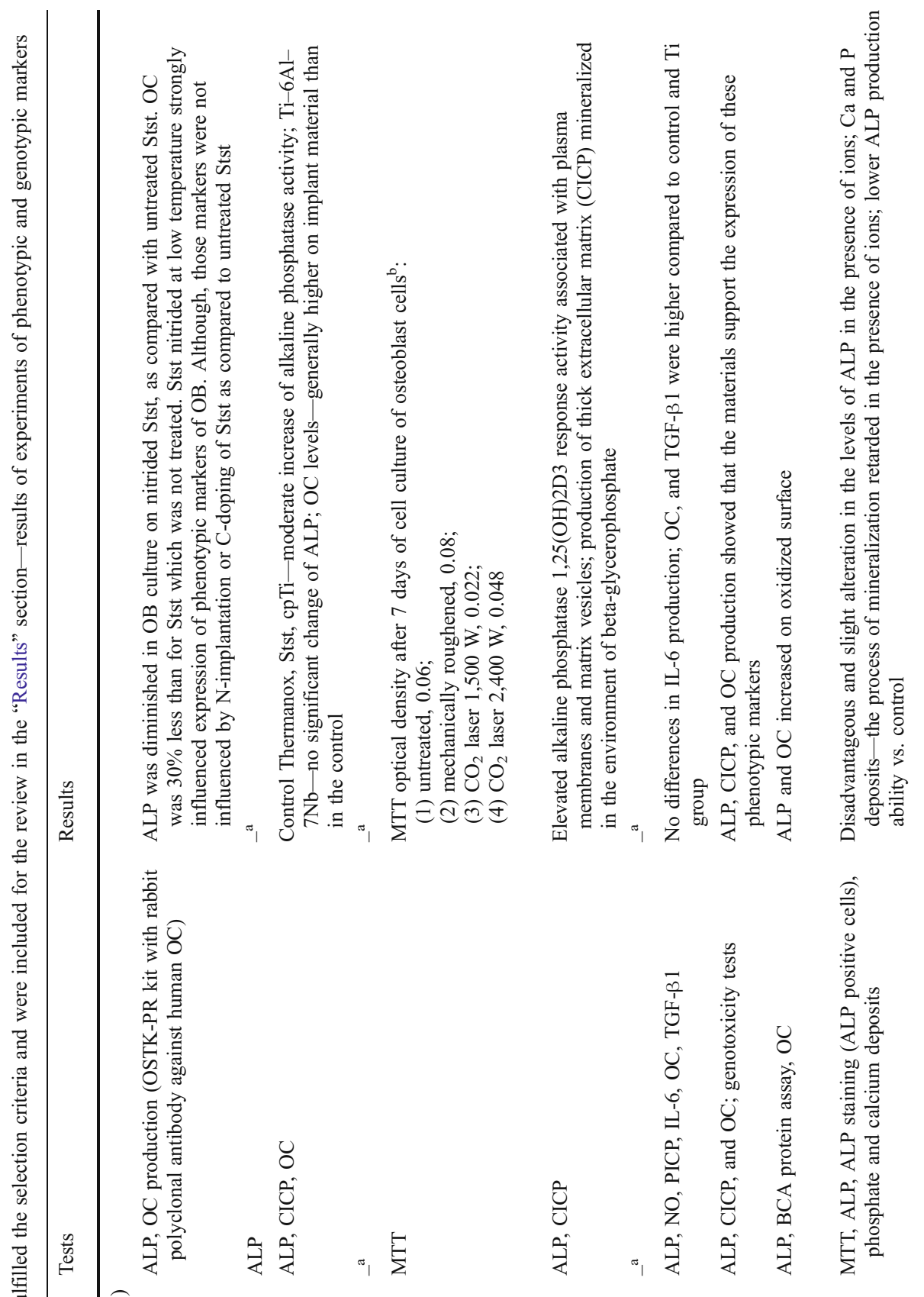



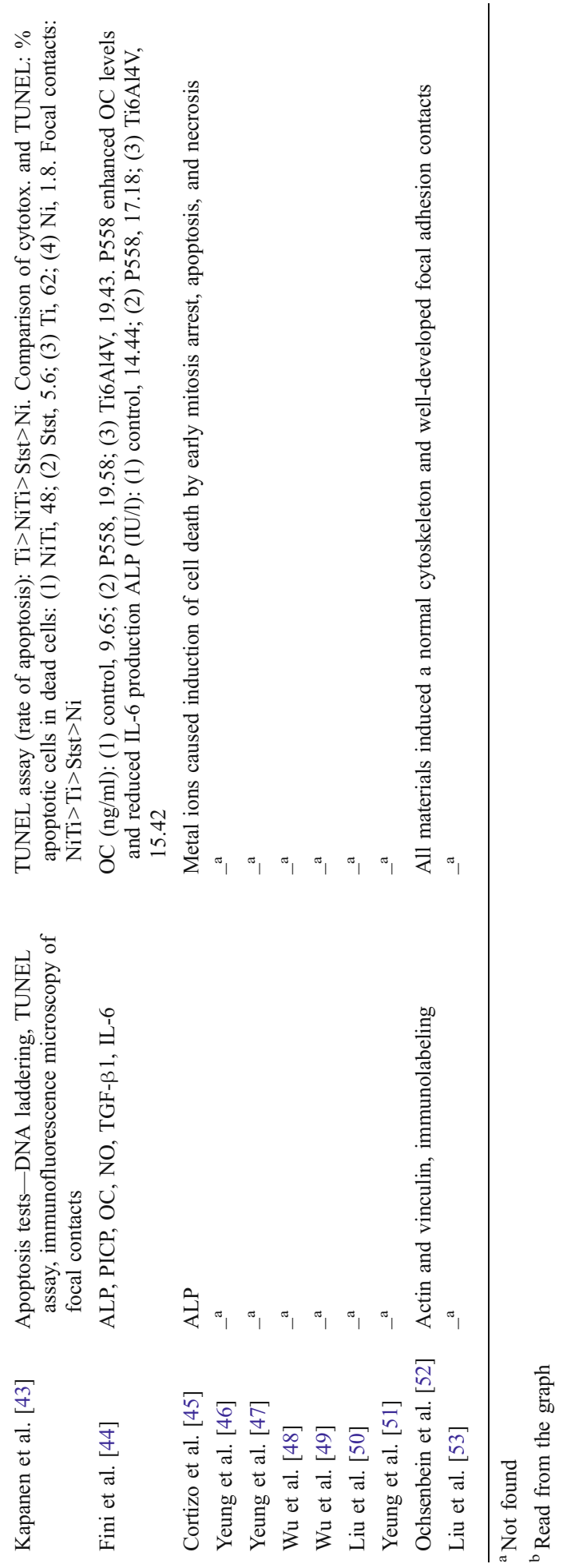


\section{Cell Culture Experiments-Results}

Cell proliferation was usually investigated by counting with the use of hemacytometer grid and expressed as cell number per square centimeter. The cells were then used in cell viability assay, and measurement of the content of cell protein was performed. Cell viability was assessed by staining and counting the number of cells. Stained cells were dead cells, because the dye penetrated into their interior. The results are presented as percent of living cells (not stained). Evaluation of cell protein content is based on dissolution of cell membrane with detergent. This enables to obtain protein lysates from cells. In the method, a calibration curve is prepared. The curve is based on colorimetric determination of bovine serum albumin (Table 4).

The results of viability and proliferation tests showed the following biocompatibility order: $\mathrm{Stst}>\mathrm{NiTi}>\mathrm{Ti}$ and $\mathrm{Ti}$ alloys $>\mathrm{Ni}$. The determination of dead vs. live cells revealed the following sequence: $\mathrm{NiTi}>\mathrm{Ti}>\mathrm{Stst}>\mathrm{Ni}$. Cell surviving showed the best properties of Nitinol $>$ control, $\mathrm{Pt}, \mathrm{Pd}>\mathrm{Au}>\mathrm{Ag}>>\mathrm{Cu}$ [45]. No changes in morphology and no strong negative effect on proliferation and differentiation of $\mathrm{OB}$ were detected (Table 4).

Table 5 reports descriptive results of phenotypic/genotypic markers.

\section{Phenotypic/Genotypic Markers-Tests and Results}

In the papers discussed in the present systematic review, the response of $\mathrm{OB}$ to the materials was determined by investigation of phenotypic markers, including biochemical (ALP, CICP, OC, MTT (enzymatic reduction of 3-(4,5-dimethylthiazol-2-yl)-2,5-diphenyltetrazolium bromide), NO (nitric oxide), immunoassays) and histochemical (identification of ALP positive cells, as well as calcium and phosphates deposits) tests [42]. ALP is used to determine cell viability by the measurement of conversion of $p$-nitrophenylphosphate into $p$-nitrophenol which is then analyzed colorimetrically. OC was assessed to determine its production capacity by $\mathrm{OB}$ and was determined by competitive radioimmunoassay with the use of polyclonal antibodies. ALP and OC are the measures of cell viability. CICP was a biochemical indicator of collagen production. In some works, transforming growth factor beta (TGF- $\beta 1$ ) was evaluated. This is a protein that controls proliferation, cellular differentiation, and other functions in cells. Cytochemical assays (actin and vinculin labeling) were measured to determine cytoskeleton development. Enzymatic reduction of MTT assay was used to evaluate both cell viability and proliferation [42]. Also, genotypic markers were determined: DNA laddering and TUNEL assay [43].

Among phenotypic markers, practically in all the studies, ALP was determined, frequently OC and CICP [33-35, 38-42, 44, 45]. Less often, interpreted markers included MTT [37], PICP (pro-collagen I) [39, 44], TGF- $\beta 1$ [39, 44], IL-6 [39, 44], actin, and vinculin [52]. In some cases, also genotoxicity tests were conducted [40], including DNA laddering and TUNEL assay [43]. Also, immune assays were performed [52]. The results of measurements of phenotypic markers were in accordance with the results obtained in cell culture experiments (proliferation and viability).

The measured values of phenotypic markers (ALP, OC, and CICP) were usually better for implanted materials, as compared with the not implanted ones [33, 35, 37, 38, 40, 41]. In particular, this concerned implanted NiTi. The results for Stst were not so clear-one paper showed the improvement of biocompatibility [35], another, the decrease [33]. It was confirmed that the presence of metal ions in the growth medium in which OB were cultivated had inhibitory effect also on phenotypic markers [42, 45]. 
Adhesion of Cells

Adhesion of cells was found to be related with the properties of the materials, in particular with their morphology, roughness, and wettability [53]. It is thought that the main role in the initial adhesion of cells was played by wettability [53].

\section{Cell Culture Experiments on Fibroblasts}

Bordji et al. [33] investigated FB and determined fibronectin and type I collagen (CICP). High content of fibronectin in cells cultivated on untreated materials, $\mathrm{N}$-implanted, and C-doped was detected. Ryhänen et al. [34] also carried out cell culture experiments on human fibroblasts and evaluated cell proliferation and contact with the tested material. The results of cell culture of FB were similar to OB. Bogdanski et al. [36] studied fibroblasts from murine 3 T3 (proliferation and adhesion). Montanaro et al. [40] carried out experiments on FB from mouse (FB L929). Cells cultured on oxidized surfaces showed higher ALP and OC levels. Osteoblasts appeared more sensitive than fibroblasts in cytocompatibility tests [33].

General Conclusions from the Studies

\section{Solution Containing Ions}

It was found that parameters of biocompatibility were correlated with the level of ions released from the materials [45]. Morais et al. [42] identified decrease in the expression of the osteoblast phenotypic markers if the cells were cultivated in the solution of metal ions. Slight effects of released ions on osteoblast phenotypic markers and negative impact on tissue mineralization ability were confirmed [42]. The strongest effect was found for $\mathrm{Ni}$ ions [42]. ALP was most rapidly produced on the 14th day of culture in the solution containing Ni ions [42]. The percentage of simulation of MTT reduction was higher than the percentage of increase of ALP activity in the presence of metal ions vs. control [42].

Growth of MG63 on Stst was not negatively influenced as compared to alloy of Ti and the control [39]. This confirmed good biocompatibility of Stst with orthopedic application [39]. Biocompatibility of P558 and osteointegration were better in P558 than in other materials [44]. However, Yeung et al. found that among the tested materials, the worst properties were showed by Stst [51].

Good biocompatibility up to $50 \%$ of $\mathrm{Ni}$ content was found-50:50\% Ni/Ti [36]. NiTi was well tolerated by osteoblastic type ROS-17 cells [43]. Also, other studies showed good biocompatibility of NiTi and modified NiTi [48, 49]. Biocompatibility of Nitinol with human osteoblasts and fibroblasts was also good according to Ryhänen et al. [34].

Pure Ti showed the best biocompatibility among the tested materials (proliferation and enzymatic activity) [35].

Good in vitro biocompatibility of Ni-free alloy was confirmed. Therefore, it was concluded that the material can be potentially used in orthopedics [40].

\section{The Effect of Treatment on Biocompatibility}

Practically in all the studies, the advantageous effect of various treatment techniques on biocompatibility of the materials was proved [41]. Yeung et al. found that biocompatibility was improved by the implantation with $\mathrm{N}_{2}, \mathrm{C}_{2} \mathrm{H}_{2}$, and $\mathrm{O}_{2}$ [47]. Yeung et al. [53] confirmed that the release of Ni ions was reduced, as compared with NiTi which was not treated. 
The most biocompatible materials were those treated by nitrogen implantation [46]. Dramatic cellular reactions were observed in contact with nitrided Stst [33]. N-PIII significantly improved the biocompatibility and mechanical properties [50]. Nitridization resulted in increased proliferation of cells [51]. Oxide layers were thin, pure, and nanostructured [52].

Plasma-treated materials showed better cytocompatibility, improved adhesion, and proliferation of OB [46]. Plasma implantation caused reduced delamination. Consequently, N-PIII significantly improved biocompatibility of NiTi [51]. Ion-implanted and carboncoated materials were more biocompatible [33]. Cells adhered better and grew faster on the materials treated with $\mathrm{CO}_{2}$ laser [37].

\section{Conditions of Treatment}

Conditions of treatment had substantial effect on the properties of the materials. Cytocompatibility diminished if the alloys were oxidized at higher temperatures [48, 49]. Cell cultures (no cytotoxicity) and results of additional experiments showed the best cytocompatibility of NiTi alloys oxidized at $450^{\circ} \mathrm{C}$ [50]. Nanoscale surface morphology altered by the implantation frequencies affected the surface free energy and wettability of the NiTi surfaces. Osteoblast adhesion behavior and proliferation were affected [53].

\section{Cell Culture Experiments-Proliferation, Viability, Phenotypic, and Genotypic Markers}

Different responses of osteoblasts to the materials were due to the mutual action and coadjustment of different interrelated surface parameters [52]. The biomaterials did not exert any significant deleterious effects on the osteoblasts. Adhesion and matrix mineralization were not modified [38]. Consequently, the conclusion was that the tested materials did not interfere with physiological functions of $\mathrm{OB}$ [38]. No alteration in the production of ALP, NO, and PICP was observed [39]. Also, Montanaro et al. found no significant cytotoxicity and genotoxicity of the alloys [40]. P558 enhanced osteoblast differentiation, as confirmed by ALP [44]. The effect of P558 on osteoblast viability, PICP, TGF $\beta-1$, and tumor necrosis factor- $\alpha$ production did not significantly differ from Ti6Al4V and controls [44].

\section{Discussion}

Despite the potential toxicity of metals, alloys are widely used in, e.g., orthodontics and orthopedics, because of their unique properties: elasticity and shape memory, stiffness, hardness, endurance to tensile stresses, which prevail their application over other materials [1]. Many of metals, which are components of alloys of which orthodontic devices are made, have been identified as mutagenic, cytotoxic, and allergenic [54-68]. It is widely accepted that ions of toxic metals released in measurable amounts can cause cytotoxic effects. At present, it has not been justified, if, e.g., orthodontic treatment is related with exposure to metal ions in toxic doses from biomaterials used in therapy [9, 10].

Generally, two classes of biocompatibility tests are distinguished: screening and specific toxicity tests. The first category is rather qualitative and the latter quantitative. Screening tests included investigation of biological effects under extreme testing conditions. The second group of assays studied multiple doses in order to determine the threshold level and also the measures of acute, sub-chronic, chronic, and lifetime exposure to a given material 
or toxic substances released from them. Studies which investigate biocompatibility of materials used in orthodontics often include cytotoxicity assays in cell cultures, where proliferation, viability, morphology, lysis, propagation, and enzymatic activity were assessed [6]. Also, the molecular mechanisms were checked by investigation of increased expression and DNA binding activity of transcription factor which is critical for differentiation of OB [69]. Cytotoxicity tests should follow the requirements of ISO 10,993 guidelines and are divided into extract, direct contact, and indirect contact methods $[7,8]$.

In the papers discussed in the present systematic review, tests included the cultivation of OB in the medium in which the material was immersed or the cultivation on the surface of the material. However, many papers underlined the importance of biological corrosion caused by the attack of oral cavity flora on the materials. This is the cause that the quantity of metal ions released does not reflect the conditions of oral cavity. Actually, the contribution of microbial corrosion in the overall corrosion of dental materials has not been established [70].

The conclusion from practically all the studies was that the effect of material treatment on biocompatibility was advantageous. Better results (in some cases increased biocompatibility as compared with control) were obtained if the materials were implanted - the best results were obtained for oxidation (of, e.g., NiTi) and nitridation (of, e.g., NiTi, Ti). The formation of surface oxides or nitrides hindered the release of ions and increased proliferation and adhesion. Modification of the materials using high voltages, high frequencies, or high intensity $\mathrm{CO}_{2}$ laser treatment improved the biocompatibility of the materials, however, up to a threshold value.

The desired properties of the materials were connected with their application. Adhesion (cell attachment) of $\mathrm{OB}$ cells to surfaces of different materials, such as titanium, titanium alloys, or $\mathrm{Co}-\mathrm{Cr}$ alloys, seemed to be more relevant in the clinical assessment of orthopedic/dental implants than in orthodontics. Physical properties of the surface (roughness, grooves) play an important role in osteointegration of orthopedic devices [71]. Adhesion of cells was found to be related with the properties of the materials, including their morphology, roughness, and wettability [53]. It is thought that the main role in the initial adhesion of cells was played by wettability.

The objective of the performed in vitro experiments on osteoblasts was to simulate the conditions occurring in an organism of human, whereby a given material (implants) or solution containing ions released from the material (orthodontic devices) stayed in contact with OB. However, it is necessary to bear in mind that the conditions of OB cultivation under artificial laboratory conditions substantially differ from in vivo environment. For instance, in the cell culture experiments, evaluated human OB and OB-like, and animal OB, undergo shear stress effects throughout laboratory restricted cultivation techniques [69]. Also, the experiments were carried out under the regime of sterile environment, meaning that microorganisms were absent. While these conditions were consistent with testing orthopedic materials, they differ from the conditions of oral environment, whereby microbial corrosion plays an important role in the deterioration of biocompatibility of the materials [72]. So far, no one has evaluated the total dose to which a patient is exposed during the whole orthodontic treatment. This is related with difficulties of using invasive biomarkers of exposure from human patients.

Studies have been performed to investigate the possible connection between changes in clinical chemistry patterns in blood after the removal of dental amalgams [73] or changes of trace elements in erythrocytes/plasma, also after amalgams/other metal alloy removal [74]. Other studies concerning caries susceptibility with the relation to trace metal concentration in saliva of primary school children have been performed [75]. Additional field of the 
assessment of exposure to trace elements discussed in the literature were teeth, evaluated to reveal the relation of tooth element content of diabetics and hypertensives [76]. There is the lack of long-term studies or papers discussing effects/consequences after the treatment had been finished. Therefore, so far in the available literature, unknown are toxicological aspects related with orthodontic treatment, including dose-response relationship or estimation of the effect of the duration of the treatment and the type of the appliance used on the dose of metals released in an organism of a patient.

\section{Conclusions}

The conclusions which arose from the studies included in the present systematic review were that a variety of measures of OB function, including enzyme production, synthesis of collagen, and non-collagenous proteins, mineral production, DNA synthesis were not strongly affected by the tested materials. The conclusions from the papers are recommendations for the manufacturing process which should include the formation of artificial passivation layer. This would eliminate the stage of initial release of metal ions immediately after placement of the material in an organism of human, a phenomenon which was confirmed practically in all the papers.

The general conclusions on cytocompatibility of the materials are as follows:

1. No negative dramatic effect of the materials on proliferation, viability, or morphology (with the exception of $\mathrm{Cu}$ in one study) was detected.

2. Viability and proliferation rate were the highest in Stst, subsequently, NiTi, Ti, and its alloys, Ni. Such conclusions arose in the majority of papers, with some exceptions which appeared in experiments on animal osteoblasts.

3. Generally, covering the materials with the layer of oxides or nitrides by using different techniques and different conditions improved all biocompatibility indicators, by decreasing the susceptibility of the materials to deterioration.

Open Access This article is distributed under the terms of the Creative Commons Attribution Noncommercial License which permits any noncommercial use, distribution, and reproduction in any medium, provided the original author(s) and source are credited.

\section{References}

1. Breme J, Biehl V (1998) Metallic biomaterials. In: Black J, Hastings G (eds) Handbook of biomaterial properties. Chapman \& Hall, London, pp 135-137

2. Weber JH (2001) Nitinol as a biomedical material. In: Buschow KH, Jürgen KH, Cahn RW, Flemings MC, Ilschner B, Kramer EJ, Mahajan S (eds) Encyclopedia of materials - science and technology, vol 111. Elsevier, Amsterdam, pp 6155-6160

3. Williams DF (2001) Biomedical and dental materials: introduction. In: Buschow KH, Jürgen KH, Cahn RW, Flemings MC, Ilschner B, Kramer EJ, Mahajan S (eds) Encyclopedia of materials-science and technology, vol 1. Elsevier, Amsterdam, pp 584-592

4. Black J, Hastings G (1998) Handbook of biomaterial properties. Springer, New York

5. Williams DF (1998) In: de Putter C, de Lange K, de Groot K, Lee AJC (eds) Advances in biomaterials. Elsevier, Amsterdam, pp 11-16 
6. Es-Souni M, Es-Souni M, Fischer-Brandies H (2005) Assessing the biocompatibility of NiTi shape memory alloys used for medical applications. Anal Bioanal Chem 381:557-567

7. ISO 10993-5:2009 Biological evaluation of medical devices-Part 5: tests for in vitro cytotoxicity

8. American Society for Testing and Materials (ASTM) F136. Accessed 1 June 2010

9. Mikulewicz M, Chojnacka K (2010) Trace metal release from orthodontic appliances by in vivo studies: a systematic literature review. Biol Trace Elem Res. doi:10.1007/s12011-009-8576-6

10. Mikulewicz M, Chojnacka K (2010) Release of metal ions from orthodontic appliances by in vitro studies: a systematic literature review. Biol Trace Elem Res. doi:10.1007/s12011-010-8670-9

11. Arslan E, Iğdil MC, Yazici H, Tamerler C, Bermek H, Trabzon L (2008) Mechanical properties and biocompatibility of plasma-nitrided laser-cut $316 \mathrm{~L}$ cardiovascular stents. J Mater Sci Mater Med 19:2079-2086

12. Berger-Gorbet M, Broxup B, Rivard C, Yahia LH (1996) Biocompatibility testing of NiTi screws using immunohistochemistry on sections containing metallic implants. J Biomed Mater Res 32:243-248

13. Bogdanski D, Köller M, Bram M, Stöver D, Buchkremer HP, Choi J, Epple M, Muhr G (2002) Rapid analysis of biocompatibility with graded test samples exemplified by Ni-NiTi-Ti. Biomed Tech 47 (1):500-502

14. Bombonato-Prado KF, Bellesini LS, Junta CM, Marques MM, Passos GA, Rosa AL (2009) Microarraybased gene expression analysis of human osteoblasts in response to different biomaterials. J Biomed Mater Res A 88:401-408

15. Bosetti M, Massè A, Tobin E, Cannas M (2002) Silver coated materials for external fixation devices: in vitro biocompatibility and genotoxicity. Biomaterials 23:887-892

16. Brors D, Aletsee C, Schwager K, Mlynski R, Hansen S, Schäfers M, Ryan AF, Dazert S (2002) Interaction of spiral ganglion neuron processes with alloplastic materials in vitro. Hear Res 167:110-121

17. Brunot C, Ponsonnet L, Lagneau C, Farge P, Picart C, Grosgogeat B (2007) Cytotoxicity of polyethyleneimine (PEI), precursor base layer of polyelectrolyte multilayer films. Biomaterials 28:632-640

18. Díaz M, Sevilla P, Galán AM, Escolar G, Engel E, Gil FJ (2008) Evaluation of ion release, cytotoxicity, and platelet adhesion of electrochemical anodized $316 \mathrm{~L}$ stainless steel cardiovascular stents. J Biomed Mater Res B Appl Biomater 87:555-61

19. González-Carrasco JL, Ciapetti G, Montealegre MA, Pagani S, Chao J, Baldini N (2005) Evaluation of mechanical properties and biological response of analumina-forming Ni-free ferritic alloy. Biomaterials 26:3861-3871

20. Gough JE, Downes S (2001) Osteoblast cell death on methacrylate polymers involves apoptosis. J Biomed Mater Res 57:497-505

21. Kapanen A, Danilov A, Lehenkari P, Ryhänen J, Jämsä T, Tuukkanen J (2002) Effect of metal alloy surface stresses on the viability of ROS-17/2.8 osteoblastic cells. Biomaterials 23:3733-3740

22. Kapanen A, Kinnunen A, Ryhänen J, Tuukkanen J (2002) TGF-beta1 secretion ofROS-17/2.8 cultures on NiTi implant material. Biomaterials 23:3341-3346

23. Li Q, Zhang Q, Sun Z (2006) The study on biocompatibility of diamond-like carbon coated nickeltitanium shape memory alloy with osteoblasts cultured in vitro. Zhongguo Xiu Fu Chong Jian Wai Ke Za Zhi 20:5-8

24. Macnair R, Rodgers EH, Macdonald C, Wykman A, Goldie I, Grant MH (1997) The response of primary rat and human osteoblasts and an immortalized rat osteoblast cell line to orthopaedic materials: comparative sensitivity of several toxicity indices. J Mater Sci Mater Med 8:105-111

25. Misra RD, Thein-Han WW, Mali SA, Somani MC, Karjalainen LP (2010) Cellular activity of bioactive nanograined/ultrafine-grained materials. Acta Biomater 6:2826-2835

26. Morais S, Pereira MC (2000) Application of stripping voltammetry and microelectrodesin vitro biocompatibility and in vivo toxicity tests of AISI 316 L corrosion products. J Trace Elem Med Biol 14:48-54

27. Nicula R, Lüthen F, Stir M, Nebe B, Burkel E (2007) Spark plasma sintering synthesis of porous nanocrystalline titanium alloys for biomedical applications. Biomol Eng 24:564-567

28. Petrolati M, Abbiati G, Delaria G, Soffiatti R, Robotti P, Guerriero C (1999) A new prosthesis for the metacarpophalangeal joint. Study of materials and biomechanics. J Hand Surg Br 24:59-63

29. Santavirta S, Gristina A, Konttinen YT (1992) Cemented versus cementless hiparthroplasty. A review of prosthetic biocompatibility. Acta Orthop Scand 63:225-232

30. Shahryari A, Azari F, Vali H, Omanovic S (2009) The positive influence of electrochemical cyclic potentiodynamic passivation (CPP) of a SS316LS surface on its response to fibronectin and preosteoblasts. Phys Chem Chem Phys 11:6218-6224

31. Tschon M, Fini M, Giavaresi G, Borsari V, Lenger H, Bernauer J, Chiesa R, Cigada A, Chiusoli L, Giardino R (2005) Soft tissue response to a new austenitic stainless steel with a negligible nickel content. Int J Artif Organs 28:1003-1011 
32. Woodruff MA, Jones P, Farrar D, Grant DM, Scotchford CA (2007) Human osteoblast cell spreading and vinculin expression upon biomaterial surfaces. J Mol Histol 38:491-499

33. Bordji K, Jouzeau JY, Mainard D, Payan E, Delagoutte JP, Netter P (1996) Evaluation of the effect of three surface treatments on the biocompatibility of $316 \mathrm{~L}$ stainless steel using human differentiated cells. Biomaterials 17:491-500

34. Ryhänen J, Niemi E, Serlo W, Niemelä E, Sandvik P, Pernu H, Salo T (1997) Biocompatibility of nickeltitanium shape memory metal and its corrosion behavior in human cell cultures. J Biomed Mater Res $35: 451-457$

35. Schmidt C, Ignatius AA, Claes LE (2001) Proliferation and differentiation parameters of human osteoblasts on titanium and steel surfaces. J Biomed Mater Res 54:209-215

36. Bogdanski D, Köller M, Müller D, Muhr G, Bram M, Buchkremer HP, Stöver D, Choi J, Epple M (2002) Easy assessment of the biocompatibility of $\mathrm{Ni}-\mathrm{Ti}$ alloys by in vitro cell culture experiments on a functionally graded Ni-NiTi-Ti material. Biomaterials 23:4549-4555

37. Hao L, Lawrence J, Phua YF, Chian KS, Lim GC, Zheng HY (2005) Enhanced human osteoblast cell adhesion and proliferation on 316 LS stainless steel by means of $\mathrm{CO}_{2}$ laser surface treatment. J Biomed Mater Res B Appl Biomater 73:148-156

38. Riccio V, Della Ragione F, Marrone G, Palumbo R, Guida G, Oliva A (1994) Cultures of human embryonic osteoblasts. A new in vitro model for biocompatibility studies. Clin Orthop Relat Res 308:73-78

39. Torricelli P, Fini M, Borsari V, Lenger H, Bernauer J, Tschon M, Bonazzi V, Giardino R (2003) Biomaterials in orthopedic surgery: effects of a nickel-reduced stainless steel on in vitro proliferation and activation of human osteoblasts. Int J Artif Organs 26:952-957

40. Montanaro L, Cervellati M, Campoccia D, Arciola CR (2006) Promising in vitro performances of a new nickel-free stainless steel. J Mater Sci Mater Med 17:267-275

41. Michiardi A, Engel E, Aparicio C, Planell JA, Gil FJ (2008) Oxidized NiTi surfaces enhance differentiation of osteoblast-like cells. J Biomed Mater Res A 85:108-114

42. Morais S, Sousa JP, Fernandes MH, Carvalho GS (1998) In vitro biomineralization by osteoblast-like cells. I. Retardation of tissue mineralization by metal salts. Biomaterials 19:13-21

43. Kapanen A, Ilvesaro J, Danilov A, Ryhänen J, Lehenkari P, Tuukkanen J (2002) Behaviour of Nitinol in osteoblast-like ROS-17 cell cultures. Biomaterials 23:645-650

44. Fini M, Nicoli Aldini N, Torricelli P, Giavaresi G, Borsari V, Lenger H, Bernauer J, Giardino R, Chiesa R, Cigada A (2003) A new austenitic stainless steel with negligible nickel content: an in vitro and in vivo comparative investigation. Biomaterials 24:4929-4939

45. Cortizo MC, De Mele MF, Cortizo AM (2004) Metallic dental material biocompatibility in osteoblast like cells: correlation with metal ion release. Biol Trace Elem Res 100:151-168

46. Yeung KW, Poon RW, Liu XY, Ho JP, Chung CY, Chu PK, Lu WW, Chan D, Cheung KM (2005) Investigation of nickel suppression and cytocompatibility of surface-treated nickel-titanium shape memory alloys by using plasma immersion ion implantation. J Biomed Mater Res A 72:238-245

47. Yeung KW, Poon RW, Liu XY, Ho JP, Chung CY, Chu PK, Lu WW, Chan D, Cheung KM (2005) Corrosion resistance, surface mechanical properties, and cytocompatibility of plasma immersion ion implantation-treated nickel-titanium shape memory alloys. J Biomed Mater Res A 75:256-267

48. Wu S, Liu X, Chan YL, Ho JP, Chung CY, Chu PK, Chu CL, Yeung KW, Lu WW, Cheung KM, Luk KD (2007) Nickel release behavior, cytocompatibility, and superelasticity of oxidized porous singlephase NiTi. J Biomed Mater Res A 81:948-955

49. Wu SL, Chu PK, Liu XM, Chung CY, Ho JP, Chu CL, Tjong SC, Yeung KW, Lu WW, Cheung KM, Luk KD (2006) Surface characteristics, mechanical properties, and cytocompatibility of oxygen plasmaimplanted porous nickel titanium shape memory alloy. J Biomed Mater Res A 79:139-146

50. Liu XM, Wu SL, Chan YL, Chu PK, Chung CY, Chu CL, Yeung KW, Lu WW, Cheung KM, Luk KD (2007) Surface characteristics, biocompatibility, and mechanical properties of nickel-titanium plasmaimplanted with nitrogen at different implantation voltages. J Biomed Mater Res A 82:469-478

51. Yeung KW, Poon RW, Chu PK, Chung CY, Liu XY, Lu WW, Chan D, Chan SC, Luk KD, Cheung KM (2007) Surface mechanical properties, corrosion resistance, and cytocompatibility of nitrogen plasmaimplanted nickel-titanium alloys: a comparative study with commonly used medical grade materials. J Biomed Mater Res A 82:403-414

52. Ochsenbein A, Chai F, Winter S, Traisnel M, Breme J, Hildebrand HF (2008) Osteoblast responses to different oxide coatings produced by the sol-gel process on titanium substrates. Acta Biomater 4:1506-1517

53. Liu XM, Wu SL, Chu PK, Chung CY, Chu CL, Chan YL, Lam KO, Yeung KW, Lu WW, Cheung KM, Luk KD (2009) Nano-scale surface morphology, wettability and osteoblast adhesion on nitrogen plasmaimplanted NiTi shape memory alloy. J Nanosci Nanotechnol 9:3449-3454

54. Lewis CG, Sunderman FW (1996) Metal carcinogenesis in total joint arthroplasty. Animal models. Clin Orthop 329(suppl):264-268 
55. Kasprzak KS, Bialkowski K (2000) Inhibition of antimutagenic enzymes, 8-oxo-dGTpases, by carcinogenic metals. J Inorg Biochem 79:231-236

56. Pereira ML, Silva A, Tracana R, Carvalho GS (1994) Toxic effects caused by stainless steel corrosion products on mouse seminiferous cells. Cytobios 77:73-80

57. Veien NK, Bochhorst E, Hattel T, Laurberg G (1994) Stomatitis or systemically-induced contactdermatitis. Contact Dermat 30:210-213

58. Al-Waheidi EM (1995) Allergic reaction to nickel orthodontic wire: a case report. Quintessence Int 26:385-387

59. Dunlap CL, Kirk Vincent S, Barker BF (1989) Allergic reaction to orthodontic wire: report of a case. J Am Dent Assoc 118:449-450

60. Basketter DA, Briatico-Vangosa G, Kaestner W, Lally C, Bontinck WJ (1993) Nickel, cobalt and chromium in consumer products: a role in allergenic contact dermatitis? Contact Dermat 28:15-25

61. Bass JK, Fine H, Cisneros GJ (1993) Nickel hypersensitivity in the orthodontic patient. Am J Orthod Dentofac Orthop 103:280-285

62. Greig DGM (1983) Contact dermatitis reaction to a metal buckle on a cervical headgear. Br Dent J $155: 61-62$

63. Hayes RB (1997) The carcinogenicity of metals in humans. Cancer Causes Control 8:371-385

64. Janson GRP, Dainesi EA, Consolaro A, Woodside DG, de Freitas MR (1998) Nickel hypersensitivity reaction before, during, and after orthodontic therapy. Am J Orthod Dentofacial Orthop 113:655-660

65. Jensen CS, Menné T, Lisby S, Kristiansen J, Veien NK (2003) Experimental systemic contact dermatitis from nickel: a dose response study. Contact Dermat 49:124-132

66. Kolokitha O, Kaklamanos EG, Papadopoulos MA (2008) Prevalence of nickel hypersensitivity in orthodontic patients: a meta-analysis. Am J Orthod Dentofacial Orthop 134:722.e1-722.e12

67. Kerosuo H, Kullaa A, Kerosuo E, Kanerva L, Hensten-Pettersen A (1996) Nickel allergy in adolescents in relation to orthodontic treatment and piercing of ears. Am J Orthod Dentofacial Orthop 109:148-154

68. Oller AR, Costa M, Oberdorster G (1997) Carcinogenicity assessment of selected nickel compounds. Toxicol Appl Pharmacol 143:152-166

69. Ethieer CR, Simmons CA (2007) Cellular biomechanics, biomechanics-from cells to organisms. Cambridge University Press, Cambridge, pp 97-98

70. Fors R, Persson M (2006) Nickel in dental plaque and saliva in patients with and without orthodontic appliances. Eur J Orthod 28:292-297

71. Swee HT (2004) Engineering materials for biomedical applications. World Scientific, Singapore

72. Perego P, Fabiano B (1999) Corrosion, microbial. In: Flickinger MC, Drew SW (eds) Encyclopedia of bioprocess technology: fermentation, biocatalysis and bioseparation. Wiley, New York, pp 717-726

73. Frisk P, Lindvall A, Hudecek R, Lindh U (2006) Decrease of trace elements in erythrocytes and plasma after removal of dental amalgam and other metal alloys. Biol Trace Elem Res 113:247-259

74. Frisk P, Danersund A, Hudecek R, Lindh U (2007) Changed clinical chemistry pattern in blood after removal of dental amalgam and other metal alloys supported by antioxidant therapy. Biol Trace Elem Res 120:163-170

75. Shigemi T, Tanaka T, Hayashida Y, Maki K (2008) Study of salivary strontium and silver concentrations in primary school children related to dental caries. Biol Trace Elem Res 123:80-90

76. Nagaraj G, Sukumar A, Nandlal B, Vellaichamy S, Thanasekaran K, Ramanathan AL (2009) Tooth element levels indicating exposure profiles in diabetic and hypertensive subjects from Mysore, India. Biol Trace Elem Res 131:255-262 